first publication at the age of nineteen, was the study of France. Henry Ehrmann's book, Organized Business in France (1958) was important in many respects. It was the first major study of the CNPF (it is still in print), and the first study to probe deeply into the practices of organized big business. He always took great pride in the research skill that he demonstrated in this study, and, though dated, the book remains the baseline from which other work on this subject must be compared. Politics in France, now in its fifth edition (1992), was first published in 1968, and it remains, to the best of my knowledge, the longest-published text on French politics in the United States. Although he and I collaborated fully in the last edition, this book will always reflect the intellectual breadth and depth of Henry Ehrmann. Over a span of twenty years he created what Pascal Perrineau, in a review of the book in France, called ". . . a work that has become an altogether remarkable overseas classic on French political life." The esteem with which he is regarded in France is reflected in the Palmes Academiques, awarded by the French government in 1977 , but most of all in the honorary doctorate that he received from the Institut d'Etudes Politiques de Paris in 1989.

Henry loved life. He skied and hiked, kayaked on the Connecticut river until a few years ago, and swam regularly until a few weeks before his death. Like most of us, he resented the toll that age exacted. But he lived a full life, and continued to contribute to our lives until the day he died.

Martin A. Schain

New York University

\section{Louise Byer Miller}

Louise Byer Miller died after a lengthy illness on August 16, 1994 in Menands, New York. Professor Miller was to begin a tenure-track appointment in Political Science and Women's Studies at West Georgia College in the fall of 1994.
Louise received her B.A. in political science and American history from The City College of New York and her Ph.D. in political science from the University at Albany in 1983. She earned the distinction of being the first woman to receive a doctorate in that department. Since then, she had taught at the undergraduate and graduate levels at SUNY at Albany, Union College, Russell Sage's Junior College of Albany, and Central Michigan University in the areas of American politics and law.

Louise was a dedicated and successful teacher who proved equally comfortable in a traditional university classroom and in non-traditional settings. Over the past decade, she worked for the New York Council for the Humanities, giving lectures on women in the law to non-profit organizations, and as mentor and administrator for Empire State College, a distance learning institution. She was also the instructor for the American Legion Auxiliary's Empire Girls State from 1988-1994, where she directed several hundred high school seniors in a week-long program on the political process and government.

An active scholar, Louise was in the process of writing a manuscript, The Supreme Court and Gender Equality, at the time of her death. A book chapter, "Wollstonecraft, Gender Equality and the U.S. Supreme Court,"' is forthcoming in Feminism and Mary Wollstonecraft, edited by Maria Falco (Penn State University Press). Louise's publications included articles on federalism and the Burger Court in Publius and Policy Studies Journal. She was also a frequent participant at APSA meetings.

Louise is survived by her husband, Ron, and her children Matthew, of Washington, DC, and Julie, a student at Wellesley College. She will be greatly missed by her colleagues and students at all the institutions with which she was affiliated.

Judith A. Garber

University of Alberta

Martin Edelman

University at Albany

\section{Edward Shils}

Edward Shils, a Distinguished Service Professor at the University of Chicago and one of the world's most influential sociologists, died January 23, 1995 in his Chicago home of cancer. Shils, 84 , was internationally renowned for his research on the role of intellectuals and their relations to power and public policy.

His scholarship was recognized in 1983 by the Balzan Foundation, Milan, with the awarding of the Balzan Prize, an honor given in fields in which the Nobel Prize is not awarded. Shils was recognized for his "important, innovative, and unique contribution to contemporary sociology." In 1979, he was selected by the National Council on the Humanities to give the Jefferson Lecture, the highest national award given in that field.

The Times (of London) Higher Education Supplement, writing of Shils, said, "He is essentially an intellectual's intellectual and scarcely a single corner of the Western cultural tradition has not benefited from the illumination afforded by his penetrating and often pungent attention."

His great knowledge of the literatures of so many cultures and so many fields was a source of wonderment to many of his colleagues. He taught sociology, social philosophy, English literature, history of Chinese science and many other subjects to students who went on to become the leading scholars in their fields throughout the world.

"He was a scholar of the highest eminence," said Sir Hugh LloydJones, formerly professor of Greek at Oxford University. 'He's made great contributions to all the humanistic sciences."

His beginnings as a sociologist and social philosopher came when, as a 17-year-old high school student in Philadelphia, he discovered the works of German sociologist Max Weber. He continued to study and write about Weber throughout his career. As a young researcher at the University of Chicago, he translated the works of sociologist Karl Mannheim into English. $\mathrm{He}$ became the bridge between 